\title{
ЕКОЛОГО-ПРАВОВЕ РЕГУЛЮВАННЯ РАЦІОНАЛЬНОГО ВИКОРИСТАННЯ ЗЕМЕЛЬНИХ РЕСУРСІВ
}

\section{Рецензент - кандидат сільськогосподарських наук М. М. Маренич}

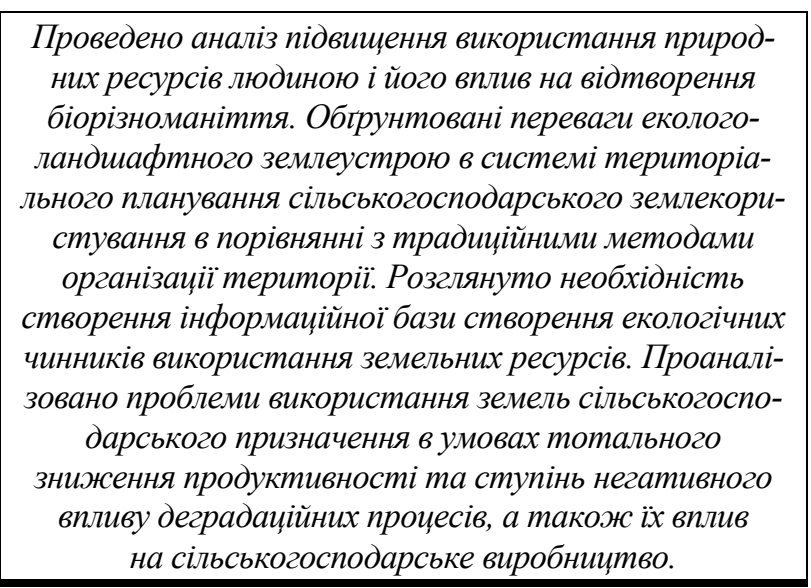

Ключові слова: ринок земель, природні екосистеми, біорозмаїття, еколого-ландшафтне обтрунтування, окультурення трунтів.

Постановка проблеми. Сучасний стан земель в Україні не відповідає їх продуктивному потенціалу, вимогам раціонального природокористування [4]. Близько $92 \%$ земельного фонду залучено до господарського обігу, внаслідок чого порушено екологічний стан навколишнього природного середовища та сільськогосподарських ландшафтів. Переважна частина земель піддається водній та вітровій ерозії, техногенному забрудненню, дегумуфікації, руйнуванню структури грунту. Внаслідок цих й інших негативних процесів має місце порушення родючості грунтового покриву, що обумовлює падіння екологічної ефективності землекористування.

Аналіз основних досліджень і публікацій, у яких започатковано розв'язання проблеми. Як свідчать літературні дані, вагомий внесок у розвиток науково-методологічних засад формування еколого-економічних підходів щодо організації раціонального використання земель сільськогосподарського призначення зробили такі науковці, як Д. І. Бабміндра, Д. С. Добряк, Й. М. Дорош, О. П. Канаш, М. М. Федоров та інші. Вони обгрунтували принципи та методи управління земельними ресурсами, у тому числі й у сільськогосподар- ській діяльності [2]. Водночас методологія та методика еколого-економічного обгрунтування раціонального використання земель сільськогосподарського призначення на засадах прогнозів та планів перспектив еколого-економічного розвитку залишаються значною мірою дискусійними [1].

Мета і завдання роботи. Мета: даним дослідженням передбачається визначити проблеми та переваги еколого-правового регулювання раціонального використання земельних ресурсів, а також питання захисту грунтів та екологічне стимулювання суб'єктів землекористування за діяльність, пов'язану з охороною земель.

Завдання: викласти методологічні засади та проаналізувати методику формування організації території землекористування сільськогосподарського підприємства на засадах еколого-ландшафтного землеустрою; вивчити питання захисту грунтів від ерозії за сучасного реформування земельних відносин.

Матеріали та методика дослідження. Матеріал дослідження - грунти та земельні ресурси. Методика дослідженя полягала в аналізі та визначенні екологічного стимулювання використання земельних ресурсів.

Результати дослідження. Джерелом екологічного стимулювання суб'єктів землекористування $\epsilon$ кошти від сплати земельного податку, а також кошти інноваційних фондів або інших позабюджетних джерел. Екологічне стимулювання суб'єктів землекористування за діяльність, пов'язану з охороною земель, здійснюється виключно внаслідок виконання умов спеціальних угод. У необхідних випадках (за домовленістю сторін) оформляються додатки до спеціальної угоди, в яких визначаються особливі умови виконання окремих заходів. Зазначені додатки є невід'ємною частиною спеціальної угоди. Види та обсяги економічного стимулювання визначаються по кожному із заходів окремо, а також у цілому на територію, де суб'єкти землекористування здійснюють землеохоронні заходи [2]. Останнім часом у світі загострюється боротьба за ринки земель сільськогосподарського призначення.

* Науковий керівник - доктор сільськогосподарських наук, професор П. В. Писаренко 


\section{СТОРІНКА МОЛОДОГО ВЧЕНОГО}

Такими ринками є країни, що розвиваються. Зовнішні інвестори запекло конкурують, прагнучи залишити за собою право на використання сільськогосподарських земель для виробництва продовольства в майбутньому. Згідно 3 даними Держземагентмтва України, загальна площа земель, права на які з середини першого десятиліття XXI ст. були передані іноземним інвесторам, вже майже досягла площі Західної Свропи [3]. Остання хвиля «земельної лихоманки» була викликана продовольчою кризою 2007-2008 років, проте в довгостроковій перспективі рушійні сили попиту на земельні ресурси включають збільшення чисельності населення, обсягів споживання товарів і послуг, а також ринковий попит на продовольство, біопаливо, сировину та деревину [1].

Землеустрій - як система різноманітних (екологічних, соціальних, економічних й інших) заходів - вирішує проблеми раціоналізації землекористування щодо рівнів адміністративнотериторіального поділу конкретним умовам господарської організації виробництва й природокористування. У землевпорядній літературі й практиці до раціонального прийнято відносити таке землекористування, що найповніше враховує властивості та особливості ландшафту, господарську придатність території, орієнтовану на задоволення інтересів суспільства, забезпечує високу ефективність виробничої й іншої діяльності, сприяє охороні й відтворенню продуктивних та інших корисних властивостей землі. Еколого-економічна спрямованість землеустрою очевидна. Для розвитку ефективної ринково орієнтованої системи землекористування сьогодні повинна мати пріоритет еколого-ландшафтна складова змісту землеустрою. Первинний стан землі можна розглядати у вигляді природної субстанції, вторинний - засобу виробництва або нерухомого майна. Недооцінка екологічного змісту землеустрою продовжує залишатися досить істотною, його призначення не можна обмежувати рамками реалізації земельної політики, принижуючи роль землеустрою у вирішенні корінного завдання землекористування: підвищення стійкості ландшафту, продуктивності й родючості земель, подолання продовольчого дефіциту [2].

За час земельної реформи в Україні в сфері аграрного виробництва серед якісних змін відбулася трансформація основних форм господарської діяльності сільськогосподарських товаровиробників. Так, колишні КСП перетворилися в агроформування різних організаційно-правових форм господарювання. На засадах власності на землю та оренди землі сформувалися акціонерні господарські товариства, приватні (приватноорендні) підприємства, сільськогосподарські кооперативи, фермерські господарства тощо. I вже останніми роками в нашій державі започатковано утворення нової організаційно-правової структури - агрохолдингів. Площі землекористувань таких форм господарської діяльності становлять від 30 до 330 тисяч гектарів. Нині в їхньому обробітку знаходиться щонайменше 35 \% орних земель України. Крім того, спостерігається тенденція до збільшення орендованої ними території [4].

Господарська діяльність агрохолдингів має як позитивні, так і негативні сторони. Позитивним є підвищення загальної ефективності сільськогосподарського виробництва. Значні масштаби виробництва дають можливість застосувати сучасну високопродуктивну техніку й новітні технології і завдяки їм істотно підвищувати продуктивність ресурсів, знижуючи за рахунок цього витрати на одиницю продукції [4].

Разом із тим, концентрація земель агрохолдингами шляхом витіснення з ринку оренди землі певної кількості невеликих і менш потужних аграрних підприємств, у тому числі й фермерських, призводить до припинення існування сільськогосподарських підприємств як юридичних осіб і створює нову соціально-економічну ситуацію на селі, що характеризується:

- втратою для певної кількості сільських мешканців роботи;

- ненадходженням до місцевих бюджетів податкових та інших платежів від агропідприємств, що припинили своє існування;

- відсутністю фінансування для створення й підтримки сільської інфраструктури [4].

Господарську діяльність агрохолдингів забезпечують як власні, так і залучені фінансові ресурси компаній-засновників. Окрім того у багатьох випадках такими формуваннями використовується іноземний капітал у вигляді інвестицій. Тому значна концентрація сільськогосподарських угідь у їхньому розпорядженні може поставити Україну поряд із країнами Африки, Азії та Латинської Америки, де основні площі сільськогосподарських угідь орендують іноземні інвестори [3].

Сучасна система сільського розселення та його потенціал в Україні є досить неоднорідний. Тому в процесі формування органами державної влади аграрної політики щодо просторового розміщення сільськогосподарських землекорис- 
тувань необхідно враховувати регіональні особливості держави. Для окремого регіону чи природно-сільськогосподарської зони можуть створюватися свої науково обгрунтовані форми господарювання 3 оптимальними розмірами землекористувань [1]. Не виключається існування також i агрохолдингів. Однак у такому випадку мета кожного 3 таких формувань повинна бути спрямована на сталий розвиток сільських територій, який задовольняє потреби нинішнього часу, не ставлячи під загрозу здатність майбутніх поколінь забезпечувати свої власні потреби [2].

Виклики, що ставить світова економіка до забезпечення кількістю продовольства, i разом із тим, перехід України до ринкових відносин та вступ iii до СОТ, спонукають нашу державу рухатися в напрямку виробництва сільськогосподарської продукції. Для цього слід ефективно розпоряджатися виробничими, кадровими і фінансовими ресурсами сільськогосподарських підприємств, кваліфіковано оцінювати кон'юнктуру ринку й запобігати можливим негативним чинникам навколишнього середовища. Розуміння цих проблем, правильна маркетингова стратегія, ефективне використання всього ресурсного i технологічного потенціалу аграрних підприємств можуть забезпечити позитивні результати.

У теоретичному відношенні питання екологоландшафтного обгрунтування організації території сільськогосподарських підприємств розроблені глибше стосовно практичного застосування результатів наукових досліджень. Від загальних пропозицій еколого-ландшафтного характеру здійснюється перехід до ретельного врахування вимог рослин щодо середовища їхнього вирощення. Великі надії в цьому разі покладаються на удосконалення теоретичних основ територіального планування землекористування [1].

Постановка досліджень із еколого-ландшафт-

\section{БІБЛІОГРАФІЯ}

1. Бистряков I. К. Методологічні аспекти розвитку земельних відносин в рамках територіальних землегосподарських систем // Матеріали міжнародної наукової конференції, м. Київ, 28 жовтня 2011 р. / Рада по вивченню продуктивних сил України НАН України. - С. 13-16.

2. Третяк A. M. Еколого-ландшафтний землеустрій сільськогосподарських підприємств. - К. : ЦЗРУ, 2005. - 85 с.

3. Третяк A. М. Стратегія реформування земель- ного обгрунтування землеустрою не означає, що діюча ієрархічна структура організації території не враховує екологічних властивостей землі. Вона формувалася протягом тривалого періоду i неминуче змушена була орієнтуватися (свідомо чи стихійно) на різну якість ландшафту, зональні й місцеві умови, придатність землі.

Розходження в екологічній якості реалізуються у ході визначення параметрів системи сільськогосподарського землекористування, форм власності на землю та господарювання, спеціалізації й розмірів території та виробництва, складу угідь і посівів, типів, видів, кількості й розміщення сівозмін, тобто при формуванні агроекосистем різного призначення. Таким чином, створюється територіально-виробнича інфраструктура для самодостатнього функціонування суб'єкта, який господарює в обраному напрямі діяльності, ефективної організації землеробства, раціонального природокористування. Врахування екологічних показників забезпечує збереження системи землекористування, виробництва, трудових й інших ресурсів.

Висновок. Обгрунтовано переваги екологоландшафтного землеустрою в системі територіального планування сільськогосподарського землекористування порівняно зі звичайними методами землеустрою території, який полягає у кращій відповідності організації території вимогам розвитку економіки й природокористування. До останніх відносяться цілісність, комплексність методів та заходів щодо організації використання й охорони земель, забезпечення узгодженості інтересів землекористувачів через балансові відносини природних та економічних ресурсів, довгострокове збереження системоутворюючих елементів територіального устрою, багатоваріантність моделей, конструкцій та проектних рішень тощо.

ної політики в Україні на сучасному етапі // Землевпорядний вісник. - 2012. - № 3. - С. 12-21.

4. Хвесик M. А. Еколого-екологічні проблеми раціонального природокористування в сучасних умовах реформування земельних відносин: матеріали наук.-практ. конф. «Земельна реформа в Україні. Сучасний стан та перспективи подальшого вдосконалення земельних відносин» (Київ, 10-13 квіт. 2011 р.). - К. : Знання, 2011. - С. 19-22. 